NBER WORKING PAPER SERIES

\title{
CAPITAL ACCOUNT LIBERALIZATION \\ AND GROWTH: WAS MR. MAHATHIR RIGHT?
}

\author{
Barry Eichengreen \\ David Leblang \\ Working Paper 9427 \\ http://www.nber.org/papers/w9427 \\ NATIONAL BUREAU OF ECONOMIC RESEARCH \\ 1050 Massachusetts Avenue \\ Cambridge, MA 02138 \\ December 2002
}

Financial support from NSF grants \# SES -9986472 to Leblang and \# SES - 9986273 to Eichengreen is gratefully acknowledged. We are grateful to Andrea Little for excellent research assistance. For comments we thank Carlos Arteta, Michael Bordo, Jim Corr, Jeff Frieden, Michael Hutchison, Olivier Jeanne, Hans-Voachim Voth, Charles Wyplosz, and seminar participants at the Bank of Thailand. The views expressed herein are those of the authors and not necessarily those of the National Bureau of Economic Research.

C 2002 by Barry Eichengreen and David Leblang. All rights reserved. Short sections of text not to exceed two paragraphs, may be quoted without explicit permission provided that full credit including, (C) notice, is given to the source. 
Capital Account Liberalization and Growth: Was Mr. Mahathir Right?

Barry Eichengreen and David Leblang

NBER Working Paper No. 9427

December 2002

JEL No. F3

\section{ABSTRACT}

Much ink has been spilled over the connections between capital account liberalization and growth. One reason that previous studies have been inconclusive, we show, is their failure to account for the impact of crises on growth and for the capacity of controls to limit those disruptive output effects. Accounting for these influences, it appears that controls influence macroeconomic performance through two channels, directly (what we think of as their positive impact on resource allocation and efficiency) and indirectly (by limiting the disruptive effects of crises at home and abroad). Because these influences work in opposite directions, it is not surprising that previous studies, in failing to distinguish between them, have been unable to agree whether the effect of controls tilts one way or the other. And because vulnerability to crises varies across countries and with the structure and performance of the international financial system, it is not surprising that the effects of capital account liberalization on growth are contingent and context specific. We document these patterns using two entirely different data sets: a panel of historical data for 21 countries covering the period 1880-1997, and a wider panel for the post-1971 period like that employed in other recent studies.

Barry Eichengreen

Department of Economics

University of California

Berkeley, CA

and NBER

eichengr@econ.berkeley.edu
David Leblang

Department of Political Science

University of Colorado

Boulder, $\mathrm{CO}$

leblang@sobek.colorado.edu 


\section{Capital Account Liberalization and Growth: Was Mr. Mahathir Right? ${ }^{1}$}

\section{Barry Eichengreen and David Leblang}

\section{Introduction}

The implications of capital account liberalization for economic growth are among the most contentious international monetary and financial questions of the day. Theory yields no unambiguous prediction of whether opening the capital account is growth enhancing or growth inhibiting. ${ }^{2}$ And, despite the very considerable attention lavished on the subject, the evidence is generally inconclusive. ${ }^{3}$ Social scientists are thus in the position of having little definitive to say about one of the most pressing international economic issues of our age.

One explanation for the inconclusive nature of existing analyses is that opening the capital account affects growth through two channels, which operate with different degrees of intensity in different times and places and have not been adequately distinguished. When financial markets are working well and other distortions are absent, capital flows toward sectors where its rate of return is high.

\footnotetext{
${ }^{1}$ Financial support from NSF grants \# SES -9986472 to Leblang and \# SES - 9986273 to Eichengreen is gratefully acknowledged. We are grateful to Andrea Little for excellent research assistance. For comments we thank Carlos Arteta, Michael Bordo, Jim Corr, Jeff Frieden, Michael Hutchison, Olivier Jeanne, Hans-Voachim Voth, Charles Wyplosz, and seminar participants at the Bank of Thailand.

${ }^{2}$ There is an analogy between trade in goods and trade in capital, since foreign investment is a form of intertemporal trade. The economist's presumption that trade is good for growth therefore suggests a presumption that capital mobility is good for growth. To be sure, this theoretical presumption holds only in a first-best world - that is, when other distortions are absent. A number of contributors to the recent literature argue that distortions that place us firmly in the world of the second best are likely to be even more relevant to capital-account than current-account liberalization, since information asymmetries are intrinsic to financial markets (see for example Eichengreen and Mussa et al. 1998 and Stiglitz 2002).

${ }^{3}$ Two recent surveys of this literature are Eichengreen (2002a) and Edison, Klein, Ricci and Slok (2002).
} 
banks and firms is more intense. For these reasons and others, capital account liberalization leads to a more efficient allocation of resources and to faster economic growth.

But when there are problems with the operation of domestic and international financial markets - and threats to financial stability in particular - the consequences can be less benign. If there exists an unlimited safety net or other domestic distortions conducive to excessive risk taking, opening the capital account may only lead domestic agents to further lever up their bets, increasing the risk of financial crises. ${ }^{4}$ If the international financial system is rocked by crises, capital flows may be erratic, in which case the main effect of capital account openness may be to place domestic prosperity at risk. Thus, the impact of capital account liberalization on growth is more likely to be positive when the domestic financial markets are well developed and regulated and the operation of the international financial system is smooth and stable. It is more likely to be negative when domestic and international financial markets are subject to crises.

This view resonates with interpretations of recent experience with financial crises in emerging markets, and with the Asian crisis in particular. Authors like Goldstein (1998) blame the Asian crisis, and by implication emerging-market financial problems in general, on the incompatibility of underdeveloped domestic financial markets with an open capital account. Furman and Stiglitz (1998) and Radelet and Sachs (2000), in contrast, blame the Asian crisis on the interaction of investor panic with an open capital account - that is to say, on vulnerabilities created by the operation of the international financial system. ${ }^{5}$ Krugman (1998) took this interpretation further, arguing that faced with a global financial crisis the Asian countries should

\footnotetext{
${ }^{4}$ This, then, is an illustration of the theory of the second best, alluded to in footnote 2 , where eliminating one distortion - restrictions on capital mobility - may not be welfare improving in the presence of other distortions. ${ }^{5}$ Others pointed to the appreciation of the dollar, the slowdown in the global electronics industry, and Japan's economic and financial crisis as factors aggravating Asia's difficulties, especially after Moody's downgraded Japan's sovereign debt in the spring of 1998 and the yen fell below 140 to the U.S. dollar, prompting fears of a competitive
} 
insulate themselves from instability abroad and reflate their economies behind the shelter of controls. The Malaysian prime minister Mohamad ben Mahathir followed the approach when he slapped controls on capital flows in September $1998 .^{6}$

In this paper, we reconsider cross-country experience with capital account liberalization and growth. Unlike previous analyses, we allow an open capital account (and, by implication, capital controls) to influence growth through two channels: directly and through their tendency to diminish or magnify the macroeconomic effects of crises. Using different data sets covering different periods and different country samples, we consistently find that the most robust effect of capital controls operates via the impact of crises. While crises depress growth when the capital account is open, controls neutralize this effect. There is also weak evidence, mainly for the recent period, that the direct effect of capital account openness on growth is positive once we control for the indirect impact operating through the disruptive effects of crises (and for the tendency for controls to neutralize those disruptive effects). But the operative word here is "weak." In line with other recent studies, we conclude that it is hard to identify a robust effect of capital account liberalization on growth. Our contribution is to demonstrate the importance of controlling for crises and for the ability of controls to neutralize the disruptive effects of crises on growth when seeking to pin down the effects of capital account liberalization.

While the wide but short panels utilized in studies of capital account liberalization and growth - which typically cover anywhere from 40 to 100 countries but only three or four recent decades - offer a wealth of information on country experience, they provide little variation in the structure of the international financial system, which evolves only slowly over time. We

${ }^{6}$ When the crises in other countries had passed and stability returned to the international financial system, Malaysia 
therefore estimate the model on a panel of historical data for 21 countries covering the period 1880-1997. This has the advantage of providing more variation in the structure and performance of the international system. These data span the classical gold standard, the crisis-ridden 1920s and 1930s, the relatively stable Bretton Woods years, and the post-1971 period on which other recent studies have focused. The stability of the global financial system differs sharply across these periods, providing the variation in experience and data needed to identify systemic effects. To check the generality of our conclusions, we also estimate our model on the sort of wider, shorter panel for the post-1971 period employed in other recent studies. Reassuringly, our results carry over.

Following a brief review of literature, data and methods, we consider the impact of capital account liberalization on growth between 1880 and 1997 in the standard set-up. This yields the striking and - for many readers - counterintuitive result that capital controls are associated with faster growth. Probing deeper, we find that this effect is driven by the data for the 1920 s and 1930s, a period of pronounced financial instability. This leads us to add domestic crises and international crises to the specification, and to interact crises with controls to test whether controls operate by neutralizing the disruptive macroeconomic effects of crises in the rest of the world. A final section concludes.

\section{The Briefest Review Yet of the Literature on Capital Account Liberalization}

The literature on capital account liberalization has been surveyed repeatedly. We therefore content ourselves with the briefest possible review.

promptly removed its controls, presumably in the belief that under normalized conditions the country would again benefit from capital mobility. On Malaysian experience with controls, see Kaplan and Rodrik (1998). 
Early studies were generally not supportive of a link between capital account liberalization and growth. One of the first such analyses, by Alesina, Grilli and Milesi-Ferretti (1994), considered the association of capital account openness with growth in 20 industrial countries from the 1950 s to the 1990 s, where openness was captured by the share of years in which transactions on capital account were unrestricted, as indicated by the relevant lines of the IMF's Annual Report on Exchange Arrangements and Exchange Restrictions. ${ }^{7}$ They found that growth effects were small and insignificant. Grilli and Milesi-Ferriti (1995) considered a larger cross section of 61 countries and a succession of five year periods and again reported largely negative results. ${ }^{8}$ Rodrik (1998) extended this approach to a still larger sample of countries and again found no stable association between capital account liberalization and growth. Bordo and Eichengreen (1998) corrected for selectivity (for the fact that controls tend to be imposed where they are likely to have the largest effect) but still found no impact on growth.

Quinn (1997) was the first systematic cross-country empirical analysis, to our knowledge, to report positive results. His study is also notable for its development of a more gradated measure of capital account liberalization. Quinn measured capital account openness on

\footnotetext{
${ }^{7}$ Like most of their successors, these authors focus on restrictions on payments for capital transactions (line E2 of the table in question). (Some investigators supplement this information with the IMF's measure of restrictions on payments for current transactions, along with in some cases its measures of surrender or repatriation requirements for export proceeds, separate exchange rates for some or all capital transactions and/or some or all invisibles, and bilateral payments arrangements with members and nonmembers.) These data have limitations. For example, the category "restrictions on payments for capital transactions" available before 1996, for example, refers exclusively to resident-owned funds and may not reflect restrictions on capital transfers by nonresidents. In addition, drawing a line between measures affecting the current and capital accounts is problematic. The category "separate exchange rate(s) for some or all capital transactions," for instance, includes measures affecting "some or all invisibles," which may include payments on current as well as capital account. Bilateral payments arrangements with members and nonmembers include not just the maintenance of separate exchange rates for capital transactions, which are directly relevant to a consideration of capital account liberalization, but also the use of one unitary rate for transactions with one country but a different unitary rate for transactions for another country, where the second kind of multiple rate is often used to discriminate among transactions on current as well as capital account. For further discussion of these problems, see Eichengreen (2002a).

${ }^{8}$ In some cases, the coefficient on capital account openness in the growth equation was significantly greater than zero, but in other cases it was significantly less.
} 
a scale ranging from zero to eight. ${ }^{9}$ He considered the impact of both capital account openness and the change in openness and reported a positive association between the change in capital account openness and growth. This study thus suggested that evidence of no effect may have been an artifact of the crude nature of proxies used by earlier authors.

Quinn's results have been questioned, however, on the grounds that policies toward the capital account may be endogenous - that they are affected by the level of income and the rate of growth. Edwards (2001) attempted to correct for this problem by using the lagged level of capital account openness, among other variables, as instruments for the current level of capital account openness. ${ }^{10}$ He continued to report a significant positive effect of capital account liberalization on growth, using the Quinn measure, but one limited to high income countries. On the other hand, Edison, Klein, Ricci and Slok (2002) find, contra Edwards, that the association of capital account liberalization with growth is stronger in emerging markets (in Asia, in particular), not in OECD economies. Arteta, Eichengreen and Wyplosz (2001) present evidence that leads one to question the robustness of the growth effects of capital account policies for both developed and developing countries. ${ }^{11}$

\footnotetext{
${ }^{9}$ As implemented, Quinn's index actually ranges from zero to four in half point increments.

${ }^{10}$ Other instruments include distance from the equator and the development of financial markets. The validity of these instruments has been questioned on the grounds that geographical variables and financial development belong in the growth equation itself, and if they are independent determinants of growth, they are not also valid instruments for capital account policies. Edison, Levine, Ricci and Slok (2002) use a different set of instruments and econometric procedures and find no stable association of capital account liberalization with growth.

${ }^{11}$ These last authors also consider the possibility that the growth effects of capital account liberalization are contingent on financial development, the strength of contracting institutions, and openness more generally. They find little evidence that those effects are significantly conditioned by a country's level of financial development. They find some (limited) support for the idea that the growth effects of capital account liberalization are more pronounced in countries with stronger contracting institutions (as measured by International Country Risk Guide's index of rule of law). They report even stronger evidence that the effects of capital account liberalization are contingent on openness generally (on whether the current account has been opened previously and whether major macroeconomic imbalances have been eliminated prior to the removal of capital account restrictions).
} 
A separate literature considers the association of capital account openness and crises. Contrary to much of the qualitative literature, where it is argued that capital account liberalization can set the stage for crises (see inter alia Furman and Stiglitz 1998), quantitative studies tend to show a positive association of capital controls with crises. Using annual data, Glick and Hutchison (2000) regress currency crises in one year on a binary measure of the presence or absence of capital controls at the end of the preceding year; in both bivariate and multivariate analyses they report a negative correlation. Leblang (2001) codes changes in capital controls monthly and finds that controls are associated with an increased probability of crises. Bordo, Eichengreen, Klingebiel and Martinez Peria (2001) extend the analysis backwards in time and similarly find a positive association of controls with crises.

One interpretation of these results, following Bertolini and Drazen (1997a,b), is that countries maintaining or imposing controls send a negative signal to the markets that undermines confidence in their commitment to sound and stable policies, which in turn applies pressure to their currencies. More generally, controls may be proxying for unobservable characteristics of countries (including the confidence of investors in their commitment to sound and stable policies) that affect the stability of their currencies and financial systems.

Strikingly, the literatures on growth and crises, and on the role of capital account liberalization in both, have few points of tangency. ${ }^{12}$ In principle, capital account liberalization may both enhance the efficiency of resource allocation, stimulating growth, and heighten financial fragility, depressing it. The net effect can only be analyzed in a framework that incorporates both possibilities.

\footnotetext{
${ }^{12}$ One exception is Gourinchas and Jeanne (2002), who consider a model in which capital account liberalization both enhances the efficiency of resource allocation and heightens the risk of self-fulfilling liquidity crises. But this
} 


\section{Data and Methods}

Our data on growth rates and capital controls are from Bordo, Eichengreen, Klingebiel and Martinez-Peria (2001), who assemble time series on national income and income per capita in 21 countries for the period 1880-1997. Their principal sources are the International Monetary Fund's International Financial Statistics for the post-World War II period and compendia of historical statistics for earlier years (for example, Mitchell 1975 and Maddison 1995). ${ }^{13}$

Descriptive statistics for these variables are shown in the appendix.

This is a longer and narrower panel than typically used in cross-country studies of growth. We have data for Argentina, Australia, Brazil, Canada, Chile, Denmark, Finland, Greece, Italy, Japan, Norway, Portugal, Spain, Sweden, United States, Belgium, France, Germany, the Netherlands, Switzerland, and Great Britain. The composition of the sample is driven by data availability and by the goal of analyzing a uniform set of countries over 12 decades. Many of today's developing countries did not exist as independent political entities before World War II. Others have been the attention of limited historical scholarship. Many had only rudimentary fiscal administrations; as a result the information needed for the retrospective reconstruction of their national accounts is not available. For all these reasons, it tends to be today's high income countries for which consistent data are available over long periods. ${ }^{14}$

paper considers a theoretical model (including a calibrated version, which is simulated), in contrast to the focus of this paper (and the rest of the present literature review), which is econometric in orientation.

${ }^{13}$ The earlier data have been constructed by economic historians retrospectively, on the basis of limited contemporary data, relying generally on information on production or expenditure by sector or component. These retrospective historical time series have been criticized as not providing an accurate picture of the volatility of cyclical fluctuations in earlier periods, since they tend to be based on commodity production, which is more volatile than other components of GNP. It is less clear, as measures of secular rates of growth, our focus here, that they are biased in one direction or the other.

${ }^{14}$ Although some countries - Greece or Chile, for example - did not have particularly high incomes early in the period while others, like Argentina, arguably fell out of this category toward its end. The last of the three 
In what follows we analyze growth over successive non-overlapping five year periods, following the practice in recent contributions to the empirical growth literature. ${ }^{15}$ Our measure of capital controls captures whether a country had controls in place during the initial year of each period. ${ }^{16}$ For recent years, we utilize the IMF's binary measure of restrictions on capital transactions, from the Fund's Annual Report on Exchange Arrangements and Exchange Restrictions (Line E.2). This source and the IMF's Annual Report have such information going back to the $1950 \mathrm{~s} .{ }^{17}$ For earlier years we construct the analogous variable from historical sources. ${ }^{18}$

We supplemented these data with measures of human capital formation, which feature prominently in other recent analyses of economic growth. We use primary and secondary school enrolment from Lindert (2001), Mitchell $(1975,1983)$ and the World Bank's World Development Report, 2000 to construct the percentage of the population between the ages 5-14 and 15-19, respectively, enrolled in primary and secondary school. This is a parsimonious specification of

explanations for this fact cited earlier in this paragraph suggests that it may not be possible to change this fundamental fact. For recent decades, it is possible to extend the data and analysis to a larger sample of countries that includes fuller representation of lower-income emerging markets (as we do below).

${ }^{15}$ We exclude the war years (1914-1918 and 1940-44) and the transitional years between the Bretton Woods System of pegged-but adjustable exchange rates and the post-Bretton Woods float (1971-72). As a result, we include a few periods that are slightly shorter (1910-13) and slightly longer (1965-70) than five years. This periodization only makes a difference in the case of international crises (defined below), where the number of crises during a period increases dramatically if 1971 is included in the sample. Five years is a relative short period over which to focus on growth effects, although this approach to constructing a panel of international comparative data is now standard in the literature. Some will argue that the resulting estimates are better interpreted as determinants of macroeconomic fluctuations rather than determinants of the trend rate of growth. But, given our eventual emphasis on the output effects of crises and the impact of capital controls, it can be argued that this focus is appropriate.

${ }^{16}$ As a robustness check we also measured capital controls as the proportion of years during each period when controls are in place. Only in the case of Table 2 does substitution of this measure make even a slight difference.

${ }^{17}$ Given the limitations of the IMF measure (discussed in Section 2 above), we also experimented with Quinn's more gradated measure of capital account liberalization, but perhaps because values are publicly available only for four years, we were unable to obtain informative results.

${ }^{18}$ Among our principal sources of information are Ellis (1941), Salera (1941), Nurkse (1944), and Diaz-Alejandro (1984). 
the determinants of growth, but it is dictated here by the need to estimate equations covering long periods of historical time. ${ }^{19}$

Our specification relates economic growth to its determinants in linear fashion:

$$
\mathrm{GROWTH}_{\mathrm{it}}=\mathrm{f}\left(\mathrm{YPC}_{\mathrm{it}}, \mathrm{PE}_{\mathrm{it}}, \mathrm{SE}_{\mathrm{it}}, \mathrm{CC}_{\mathrm{it}}\right)
$$

where GROWTH is the growth of real per-capita GDP in 1989 dollars multiplied by 100, while YPC is the log of income per capita relative to the United States PE is the log of the primary school enrolment rate, SE is the log of the secondary school enrolment rate, and CC is our measure of capital controls, all at the start of the period. The "i" subscript denotes country, while the "t" subscript denotes five-year period.

A number of problems are encountered when applying standard panel-data methods to this set-up. First, those standard estimators (much less ordinary least squares) do not take into account that the errors may be correlated over time. Nor do standard techniques take into account that variables of interest - the decision to impose or remove controls, or the incidence of financial crises (introduced below) - may be affected by the growth rate. Lastly, we want to minimize the chance that the results we obtain reflect country-specific effects for which we fail to adequately control.

To deal with these problems, we use the dynamic panel estimator of Arellano and Bond (1991) as extended by Arellano and Bover (1995) and Blundell and Bond (1997). This jointly estimates the regression in differences with the regression in levels and uses internal instruments

\footnotetext{
${ }^{19}$ Below, when we analyze a larger sample of countries in the post-1971 period, we are able to add additional independent variables from the empirical literature on growth without substantively changing the results. As a further robustness check, we also added the trade/GNP ratio, the inflation rate and financial depth to the baseline model estimated over the 1880-1997 period. While doing so reduced the sample size by approximately a quarter, it did not change the signs or significance of the variables of interest.
} 
to eliminate bias resulting from possible endogeneity of the independent variables. ${ }^{20} \mathrm{We}$ include country fixed effects to control for unmeasured country-specific factors that may influence economic growth. The resulting estimates are heteroscedasticity consistent and unbiased subject to the validity of the instrumental variables. ${ }^{21}$

\section{Basic Results}

Basic results are shown in Table 1. Column one uses the dynamic panel estimator without instrumental variables and fixed effects. Column two adds country specific fixed effects. Columns three and four mirror columns one and two but instrument for GDP per capita, primary school enrolment, secondary school enrolment, and capital controls.

The estimated growth regressions are well behaved. Growth is a declining function of initial income per capita, reflecting the catch-up process. ${ }^{22}$ Growth is faster in countries with higher secondary school enrolment rates. ${ }^{23}$

Of particular interest are the coefficients on the presence of capital controls. For the entire 117 year period, in Table 1, their coefficient is positive and significantly different from

\footnotetext{
${ }^{20}$ The estimator uses lagged levels of the independent variables as instruments for the differenced variables and lagged differences of the independent variables as instruments for the levels equation. See Beck, Levine and Loayza (1999) for an application of this method to panel growth regressions.

${ }^{21}$ For all the results we report one-step parameter estimates and standard errors. Arellano and Bond (1991) emphasize that two-step standard errors are significantly underestimated, resulting in the over-rejection of the null. ${ }^{22}$ In interpreting the coefficient, it is important to recall that initial per capita incomes are relative to the United States. Per capita incomes in domestic currency units are converted into dollars at market exchange rates, since these (and not purchasing power parity equivalents) are what are available for the entire period.

${ }^{23}$ The negative coefficient on primary school enrolment, though not often significant, is nonetheless something of a paradox. This could reflect the long lags between expenditures on primary schooling and subsequent entry into the labor market, although it may also indicate the limitations of school enrolment rates as a proxy for human capital formation. See Krueger and Lindahl (2000). While there are a variety of alternative measures of human capital formation for the post-World War II period, there are no obvious alternatives for earlier years. While early contributions to the literature on growth and convergence (e.g. Barro 1991) used measures of both primary and secondary school enrolment, many subsequent studies (e.g. Levine and Renelt 1992) have included only secondaryschool enrolment rates, perhaps because their authors discovered the same anomaly.
} 
zero at standard confidence levels, as if countries with controls grew faster than countries without them. This will be seen as vindication by the skeptics of capital account liberalization and regarded skeptically, no doubt, by its proponents. We obtain this same result with and without instrumental variables and with and without fixed effects. ${ }^{24}$ The question for this paper is thus what lies behind it.

In Table 2 we allow the rate of growth and the effects of controls to differ by monetary regime (the interwar period, the Bretton Woods years 1945-71, and the post-1971 period, which is the now standard demarcation). This enables us to see whether the result in Table 1 is driven by a particular regime. We include dummy variables not just for controls interacted with regime dummies for the interwar, Bretton Woods and post-Bretton Woods years but also those regime dummies themselves, in order to avoid attributing to the effects of controls in a period to variations in period-specific growth caused by other factors.

The first two columns of Table 2 suggest that growth was faster during the interwar years than before 1913 (the omitted alternative), after controlling for income gaps, schooling and so forth, although the difference is not significant at standard confidence levels. ${ }^{25}$ It was faster after World War II; this was true of both the Bretton Woods and post-Bretton Woods years. The key coefficients, in the second regression, interact the regime dummies with the presence of controls. (Note that there is no interaction term for the pre-1914 period, since there were no countries in these years that imposed significant controls.) These show that the earlier result - that controls are associated with faster growth - is heavily driven by the interwar period. This is the only

\footnotetext{
${ }^{24} \mathrm{We}$ prefer the results with fixed effects (and report only these below), since including a vector of country dummy variables limits the likelihood that unobserved country-specific differences in institutional quality - correlated perhaps with the presence or absence of controls - are driving our results.

${ }^{25}$ The point estimate presumably reflects the effects of output and investment foregone during World War I in the lead country as well as the followers (Eichengreen 1986) and the fact that the post-1929 slump was often relatively
} 
regime for which the coefficient on controls differs significantly from zero at standard confidence levels. This result for the interwar years is consistent with the literature suggesting that interwar capital flows were destabilizing (viz. Nurkse 1944) and that countries which insulated themselves from such flows enjoyed superior growth performance, especially in the 1930s (see e.g. Diaz-Alejandro 1984). The coefficient on capital controls under Bretton Woods is again consistent with the null that countries restricting capital mobility grew faster, although the effect is not significantly different from zero at standard confidence levels. ${ }^{26}$

Some readers may wonder whether these results hinge on the inclusion of the period before 1913 when no country had capital controls. The answer is no: the results in Table 1 are unaffected, and the only change in Table 2 is that the coefficient on controls during the Bretton Woods years, while still insignificantly different from zero, switches signs (from positive to negative). ${ }^{27}$

This pattern suggests examining more closely in which five-year periods the capital account regime had a particularly strong effect on growth. Table 3 includes interaction terms for each five year period. ${ }^{28}$ It would appear that the positive association of controls with growth is concentrated in the second half of the 1920s and the first half of the 1930s, when the interwar gold standard was in operation (on a widespread basis in the first of these subperiods and a more limited basis in the second), and when the gold standard was a notorious transmitter (through

\footnotetext{
short and mild outside the United States.

${ }^{26}$ For the post-Bretton Woods period, there is a suggestion that countries with controls grew more slowly (that financial liberalization was beneficial), but the standard error on this coefficient is very large relative to its point estimate.

${ }^{27}$ We believe that it makes sense to include these observations because the pre-1914 period contains useful information about the growth effects of crises, which must be estimated in order to accurately identify the effects of capital controls, because there were multiple crises before 1914 even if there were no controls. This is why we include the period before 1914. In fact, virtually none of the results in subsequent tables is affected when we drop the pre-1914 years. We note the exceptions below - virtually all of which reinforce our findings.

${ }^{28} \mathrm{~A}$ set of $\mathrm{t}-1$ period dummies is also included in this regression although the parameter estimates are not reported
} 
open capital markets) of financial instability. ${ }^{29}$ For the post-Bretton Woods period, the evidence that controls had positive growth effects is strongest in the period 1993-7, years culminating in the Asian crisis and its spillover to other emerging markets. ${ }^{30}$ This is consistent with the view that countries like Chile and Brazil that limited their exposure to international financial flows in this period had relatively favorable growth performance overall. ${ }^{31}$

\section{Controls and Crises}

The results in Table 3 - for example, the positive association of controls with growth in the 1930s, when financial crises were widespread - suggest that controls may affect growth by shaping the impact of crises. We therefore add measures of financial crises to our basic specification. $^{32}$

Our crisis indicators, drawn from Bordo, Eichengreen, Klingebiel and Martinez-Peria (2001), are designed to be consistent with measures of the incidence of currency and banking crises used in other recent studies. For an episode to qualify as a currency crisis, there must be a

for sake of presentation.

${ }^{29}$ See Bernanke and James (1991). We see the opposite association in the first half of the 1920s, when postwar dislocation was widespread and countries where that dislocation was greatest - and growth was correspondingly depressed - were the same ones that tended to retain wartime controls.

${ }^{30}$ During this period Argentina, Brazil, Chile, Greece, Norway and Spain had controls in place. Indeed, when we eliminate the data for 1997, shortening this final period to 1993-6, the positive and significant coefficient on controls*period goes to zero. Retaining the data for 1997 but eliminating the observations for the three Latin American countries also eliminates the result.

${ }^{31}$ This coefficient presumably picks up both the positive growth effects of foreign-financed investment in the early part of the subperiod in countries with open capital accounts and their larger output losses at its end, suggesting that, on balance, the second effect dominates. In principle, these results should not be picking up reverse causality - the tendency for countries with the most disappointing growth performance to desperately open the capital account in order to attract foreign finance - because we are using instruments to control for the endogeneity of the capital account regime. Note that the effects of controls are negative-but far from statistically significant-in the preceding period 1983-92, which includes the period when international lending started up again. Argentina, Brazil, Chile, Denmark, Finland, France, Germany, Italy, Norway, Portugal, Spain, and Sweden had controls in place during this period; Australia had controls during the 1983-1987 period.

${ }^{32}$ In principle, these crises are treated as endogenous, given our use of instruments for all the explanatory variables. Thus, the fact that crises may be affected by growth - and, for that matter, by the presence or absence of controls - 
forced change in parity, abandonment of a pegged exchange rate, or an international rescue.

Wherever possible, Bordo et al. also construct an index of exchange market pressure (a weighted average of the percentage change in the exchange rate, the change in the short-term interest rate, and the percentage change in reserves, all relative to the same variables in the center country). ${ }^{33}$ A crisis is said to occur when this index is at least one and a half standard deviations above its mean. A currency crisis is indicated when it shows up according to either measure. For an episode to qualify as a banking crisis, Bordo et al. must observe financial distress resulting in the erosion of most or all of aggregate banking system capital. ${ }^{34}$

To limit the profusion of tables, our domestic crisis measure sums the number of currency and banking crises, combined, in each five year period, rather than distinguishing crises by type. (Specifications including separate variables for both currency and banking crises do not lead to substantively different results.) Table 4 shows the consequences of augmenting the specification in Table 2 with the number of crises in the subject country in each period..$^{35}$

Column 1 shows the basic result for the entire period, with dummy variables for the interwar, Bretton Woods, and the post-Bretton Woods periods. ${ }^{36}$ Crises have a negative impact on growth, as expected. The effect of controls on growth remains positive, although smaller than before.

Column 2 adds the interaction of crises with controls. Crises continue to affect growth negatively, controls positively. In addition, the interaction of crises and controls enters

\footnotetext{
should not bias our results.

${ }^{33}$ Data limitations prevent us from constructing this index for most countries in the pre-1913 period. Great Britain is the center country before 1913, the U.S. thereafter. The components are weighted to equalize their volatilities, following standard practice in the literature.

${ }^{34}$ This is the same criterion used by Caprio and Klingebiel $(1996,1999)$ to identify systemic banking crises. The Caprio-Klingebiel indicators are simply imported for the post-1971 period.

${ }^{35}$ More precisely, this variable records the number of banking and currency crises that began during the period in question.

${ }^{36}$ Results excluding the three period dummies are virtually identical.
} 
positively, as if controls help to insulate the economy from the effects of financial disruptions, although this term does not differ from zero at conventional confidence levels.

A difficulty in gauging the relative importance of these effects is that the three variables are collinear. ${ }^{37}$ To avoid having to estimate three coefficients on three closely related variables, we constrain the coefficients on crises and on the interaction of crises and controls to be equal and opposite in sign. The null is now that controls fully insulate the economy from the effects of crises. The constraint is not rejected by the data according to the standard $\mathrm{F}$ test.

The results, in column 3, now suggest that controls matter only insofar as they insulate the economy from disruptions caused by crises. Crises in the presence of open capital markets depress growth, capital controls neutralize that effect, and controls otherwise have no additional effect. In other words, controls, when entered by themselves, no longer differ significantly from zero at standard confidence levels.

In Table 5 we allow these effects to differ by period. The results are consistent with those reported above. Crises generally reduce the rate of growth, as expected; the effect is significant at standard confidence levels before 1913 and in the interwar years. The sign is the same in the post-Bretton Woods years, though in this case the impact on growth is not significant at standard confidence levels. In the Bretton Woods period the coefficient on crises is positive, which is surprising, but again insignificant. Our inability to confirm the expected negative effect may reflect the fact that crises in this period were almost entirely currency crises - banking and twin crises were essentially absent. Twin crises involving serious banking-system problems are well known to be the most disruptive variant of the phenomenon. Earlier work by Bordo,

\footnotetext{
${ }^{37}$ The correlation between controls and controls*crisis is on the order of 0.5 , while that between crisis and controls*crisis is on the order of 0.6 .
} 
Eichengreen, Klingebiel and Martinez Peria (2001) confirms that the output losses from crises in this period were small and difficult to detect.

The important coefficients, again, are those on controls. Once we add crises, there is no longer evidence that countries with controls grew faster in the interwar years. The positive coefficient on controls remains but it is no longer significantly different from zero at standard confidence levels. The evidence that countries with controls grew faster in the Bretton Woods years remains, consistent with findings in Wyplosz (1999). However, when we drop the pre1914 years - when no country had controls - which some readers will argue is the appropriate procedure, the coefficient on this variable no longer differs from zero at standard confidence levels. And, there is no evidence that capital account liberalization had an impact on growth after 1972, one way or the other.

Did countries maintaining controls limit the disruptions caused by their crises? Once more we test this hypothesis by adding the interaction of controls with crises: the null is that the coefficient on this interaction term should be positive while the coefficient on crises entered on its own should be negative, and that the two effects should be equal, if opposite in sign.

Although the coefficient on the interaction of controls with crises is positive, as expected, for all three periods in which we observe controls (we observe none in the pre-1913 years), none of them differs significantly from zero at standard confidence levels.

Again we suspect that this reflects the multicollinearity associated with the simultaneous inclusion of controls, crises, and their interaction. ${ }^{38}$ Hence, in the second regression in Table 5 we again constrain that the coefficients on controls and on the interaction of controls and crises

38That the result reflects multicollinearity rather than the irrelevance of the variables is supported by an F test, which shows that the three variables in question are jointly significant at the 10 per cent level in the interwar years and the 
to be equal and opposite in sign. For no subperiod is the constraint rejected by the standard F test. For the interwar period the constrained regression yields the expected negative coefficient on the interaction term, which is significantly different from zero at standard confidence levels. For the post-1972 period the coefficient in question is again negative, though insignificant. The results for Bretton Woods continue to be unusual, presumably because crises in this period were unusual. $^{39}$

\section{The Role of the International System}

The domestic crises considered in Tables 4 and 5 are not those most relevant to the Krugman-Mahathir argument, which focuses on international crises that infect the domestic economy through an open capital account. We therefore consider international crises, defined as the number of crises occurring in a five year period in countries other than country $i^{40}$

Table 6 is analogous to Table 4, focusing this time on international crises. In the first column, crises affect growth negatively, while controls affect it positively. But, in contrast to Table 1, controls are not significant at the 95 per cent confidence level. In the second column we add the interaction of crises and controls. Crises depress output, the interaction of crises and controls works in the other direction and fully neutralizes the former effect, and controls on their own (entered in levels, not interacted with crises) have, if anything, a negative effect on growth

\footnotetext{
5 per cent level during Bretton Woods.

${ }^{39}$ Crises minus the interaction of crises and controls has the wrong sign under Bretton Woods, and controls by themselves continue to display a positive coefficient that differs significantly from zero at standard confidence levels.

${ }^{40}$ This is how international crises are defined in Eichengreen (2002b). When a country experiences both a currency and a banking crisis in the same year, we count this as two crises. In principle, one could argue that this should be counted as a single (twin crisis), but doing so would then attach less weight to currency and banking crises occurring in the same year than to the same events occurring a few years apart, where the evidence in fact suggests that such events are particularly disruptive when they coincide in time.
} 
(operating through their impact on efficiency and resource allocation), consistent with the priors in the introduction to this paper. While this last effect is not significant at standard confidence levels, this is one of the few results reported in this paper that changes when we drop the pre1914 period (when no country had controls); when we do so, the negative effect of controls, entered on their own, becomes significant at the 95 per cent confidence level.

To be certain that we are not mis-attributing the effects of one or more of these collinear variables to the others, we once more constrain the coefficients on crises and on the interaction of controls and crises to be equal and opposite in sign. Once more the constraint is not rejected by the data. And once more the constrained coefficients are large and statistically significant at conventional confidence levels, while controls entered on their own have no additional effect.

The results disaggregated by period, in Table 7, tell the same story. Focusing on the constrained regression at the right of the table, it again appears that the main effect of controls was to neutralize output losses from crises during the unstable interwar years. (Again, imposition of the constraint is not rejected by the standard F-test.) Again there is only weak evidence of a direct effect of controls that operates separately from their interaction with the effects of crises. Specifically, none of the six coefficients on controls (not interacted with crises) in Table 7 differs from zero at conventional confidence levels. When we drop the pre-1914 period (when no country had controls), the two coefficients for the Bretton Woods years become negative and significant at standard confidence levels, consistent with the idea that controls had a negative direct effect, presumably reflecting their impact on the efficiency of resource allocation. It would appear that the strong positive effect of controls on growth evident in Table 1 and pinpointed in the interwar years in Table 2 reflects the effectiveness of controls in neutralizing the impact of crises during the unstable interwar years. 
A final set of regressions, in Table 8, considers domestic and international crises simultaneously. The results are consistent with earlier specifications. When entered separately in column 1, capital controls and crises (both domestic and international crises) have their expected signs (positive and negative, respectively) and are significant at conventional levels. Columns 2 and 3 examine whether controls influence growth indirectly-through their insulating effect-or directly, presumably by relaxing financing constraints on investment and enhancing the efficiency of resource allocation. The results support the former view: controls are no longer significant, individually or jointly (according to the standard F-test), and the coefficients on the constrained parameters are negative and significant at conventional confidence levels. ${ }^{41}$

To take stock, the historical evidence, which features considerable variation in the financial environment, suggests that capital controls are useful for insulating countries from the negative impact of crises on growth in periods when financial instability is widespread. In periods when such instability is absent, there is some evidence that controls have adverse effects on resource allocation and growth, although this last result is sensitive to sample and specification.

\section{Additional Evidence for the Modern Period}

We now ask whether the same results carry over to a sample of more countries but a shorter period like that typically used in other recent studies of capital account liberalization. Our data cover 47 countries and the period $1975-95 .{ }^{42}$ We again consider a succession of non-

\footnotetext{
${ }^{41}$ In tests that parallel Tables 5 and 7 we also examined whether domestic and international crises have regime specific influences. The results-not reported for the sake of space-confirm our earlier findings: capital controls increase growth because they insulate the economy from domestic and international crises and this effect is especially important during the interwar years.

${ }^{42}$ All variables with the exception of the crisis and capital controls indicators were obtained from the Levine-
} 
overlapping five year periods and use the estimator proposed by Arellano, Bond, Blundell and Bover. Along with initial levels of income and schooling, we control for additional country characteristics such as inflation, government consumption, trade openness, and the black market premium, correlates that are standard in the modern cross-country growth literature and on which data have become available in recent years. ${ }^{43}$

The results, in Table 9, are striking for their consistency with those for the longer period. Consider first domestic crises. In column 1, capital controls display a positive association with growth, as in Table 1. Crises enter negatively, with a coefficient that differs significantly from zero at standard confidence levels. When we add the interaction of crises and controls, in column 2, it again becomes hard to pick out the separate effects due to multicollinearity, although the three variables are jointly significant at high levels of confidence $(F=14.63)$. In column 3 we therefore constrain the signs of crises and of crises times controls to be equal and opposite in sign. This term is negative, as expected (crises depress growth but controls neutralize their effect), and significantly different from zero. Controls on their own, entered in order to pick up effects operating through other channels, have a coefficient of zero. That is, domestic crises continue to have a significant negative impact on economic growth even after controlling for capital controls and the interaction of controls with domestic crises.

Loayza-Beck data set available at: http://www.worldbank.org/research/growth/l lbdata.htm. Crises and capital controls are from the Bordo, Eichengreen, Klingebiel and Martinez-Peria (2001) data set. The intersection of these two data sets yielded 47 countries with complete information. The countries are Argentina, Australia, Austria, Belgium, Brazil, Colombia, Costa Rica, Canada, Chile, Denmark, Ecuador, Egypt, Finland, France, Ghana, Germany, Greece, India, Indonesia, Ireland, Israel, Italy, Jamaica, Japan, Korea, Malaysia, Mexico, New Zealand, Netherlands, Norway, Pakistan, Paraguay, Peru, Philippines, Portugal, Senegal, South Africa, Sri Lanka, Spain, Sweden, Switzerland, Thailand, Uruguay, United Kingdom, United States, Venezuela, and Zimbabwe. ${ }^{43}$ None of our findings hinges on the inclusion of the variables that are added here in an effort to reassure readers who may have been worried by the relative limited numbers of controls in earlier specifications. 
In columns 4, 5 and 6 we report the same analysis for international crises. Column 6 shows the now familiar negative effect of controls, exactly neutralized by crises, when the constraint of equal coefficients of opposite signs is imposed. In addition, we now find that the direct effect of controls on growth is significantly negative. This configuration of effects is consistent with the interpretation offered in Section 1 of this paper. An open capital account has a positive impact on growth in periods when the international financial system is stable and well behaved (when our measure of international crises approaches zero). In contrast, when international crises are pervasive, controls moderate the disruptive impact on domestic output of instability abroad. In this sample, the critical number of crises in other countries that must be breeched before controls have a positive, insulating effect is 22 . This is a high number, even for a period of as long as five years. It suggests that the positive, insulating effect of capital controls on growth dominates only in periods of exceptional instability in international financial

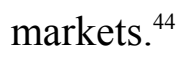

Columns 7, 8 and 9 include domestic and international crises simultaneously, for both imposing the constraint that the number of crises and the interaction of crises and controls enter with equal and opposite signs. Both domestic and international crises have their expected negative effect on growth. In both cases the presence of capital controls works to neutralize this effect. There is also a negative effect of controls not interacted with crises that is statistically different from zero at the 90 per cent confidence level when domestic and international crises are included simultaneously. These results are again consistent with the conjecture in the introduction to this paper: controls boost growth in periods of instability by insulating the

\footnotetext{
${ }^{44}$ If we weighted crises by the geographical distance between the crisis countries or the extent of trade links (as in Eichengreen and Rose 1999 or Glick and Rose 1999), we might well obtain a lower threshold number in periods
} 
economy from domestic and international crises; their direct impact on growth, operating through channels other than this insulation effect, is if anything negative.

We should acknowledge that the direct effect of controls on growth, while negative in this sample, is not well particularly well defined. This is not surprising: if there is one lesson from the recent cross-country empirical literature on capital account liberalization and growth, it is that such estimates are sensitive to sample and specification; they are a weak reed on which to hang policy advice.

\section{Conclusion}

Much ink has been spilled over the connections between capital account liberalization and growth. One reason that previous studies have been inconclusive, we have argued, is the failure to account for the impact of crises on growth and for the capacity of controls to limit those disruptive output effects. Accounting for these additional influences, it appears that controls influence macroeconomic performance through two channels, directly (what we think of as their positive impact on resource allocation and efficiency) and indirectly (by limiting the disruptive effects of crises at home and abroad). Because these influences work in opposite directions, it is not surprising that previous studies, in failing to distinguish between them, have been unable to agree whether the effect of controls tilts one way or the other.

Our results suggest that the net effect is context specific: it is positive in periods of financial instability, when the insulating capacity of controls is precious, but negative when crises are absent and the direct effect an open capital account - the positive effect on resource allocation and efficiency - tends to dominate. They suggest that capital account liberalization is 
neither plague nor panacea, that its benefits are likely to dominate its costs when the domestic financial system is robust and the international financial system is not prone to costly and disruptive crises - in periods, in other words, when the insulating capacity of controls is least valuable.

\section{References}

Alesina, Alberto, Vittorio Grilli and Gian Maria Milesi-Ferretti (1994), "The Political Economy of Capital Controls," in Leonardo Leiderman and Assaf Razin (eds.), Capital Mobility: The Impact on Consumption, Investment and Growth, Cambridge: Cambridge University Press.

Arellano, M. and S. Bond (1991), "Some Tests of Specification for Panel Data: Monte Carlo Evidence and an Application to Employment Equations." Review of Economic Studies 58:27797.

Arellano, M. and O. Bover (1995), "Another Look at the Instrumental-Variable Estimation of Error-Components Models," Journal of Econometrics 1995, pp.29-52.

Arteta, Carlos, Barry Eichengreen and Charles Wyplosz (2001), "When Does Capital Account Liberalization Help More than it Hurts?" NBER Working Paper no. 8414 (March).

Barro, Robert (1991), "Economic Growth in a Cross-Section of Countries," Quarterly Journal of Economics 106, pp.407-43

Beck, Thorsten, Ross Levine and Norman Loayza (2000), "Finance and the Sources of Growth." Journal of Financial Economics 58:261-300.

Bernanke, Ben and Harold James (1991), "The Gold Standard, Deflation and Financial Crisis in the Great Depression: An International Comparison," in R. Glenn Hubbard (ed.), Financial Markets and Financial Crises, Chicago: University of Chicago Press, pp.33-68.

Bertolini, Leonardo and Allen Drazen (1997a), "Capital Account Liberalization as a Signal," American Economic Review 87, pp.138-154.

Bertolini, Leonardo and Allen Drazen (1997b), "When Liberal Policies Reflect Shocks, What Do We Learn?” Journal of International Economics 42, pp.249-273.

Blundell, R. and S. Bond. (1998). Initial Conditions and Moment Restrictions in Dynamic Panel Data Models." Journal of Econometrics 87:115-43. 
Bordo, Michael and Barry Eichengreen (1998), "Implications of the Great Depression for the Development of the International Monetary System," in Michael Bordo, Claudia Goldin and Eugene White (eds.), The Defining Moment: The Great Depression and the American Economy in the Twentieth Century, Chicago: University of Chicago Press, pp.403-454.

Bordo, Michael, Barry Eichengreen, Daniela Klingebiel and Soledad Maria Martinez-Peria (2001), "Is the Crisis Problem Growing More Severe?" Economic Policy 24, pp.51-82.

Caprio, Gerard, Jr. and Daniela Klingebiel (1996), "Bank Insolvencies: Cross-Country Experience," Policy Research Working Paper 1620, Washington, D.C.: The World Bank.

Caprio, Gerard, Jr. and Daniela Klingebiel (1999), "Episodes of Systematic and Borderline Financial Crises," unpublished manuscript, World Bank, http://worldbank.org/html/ FinancialSectorWeb.nsf/(attachmentweb)/Crisistableproduct

Chinn, Menzie and Hiro Ito (2002), "Capital Account Liberalization, Institutions and Financial Development: Cross Country Evidence," NBER Working Paper no. 8967.

Diaz-Alejandro, Carlos (1984), "Latin America in the 1930s," in Rosemary Thorp (ed.), Latin America in the 1930s: The Role of the Periphery in World Crisis, New York: St. Martin's Press.

Edison, Hali, Michael Klein, Luca Ricci and Torsten Slok (2002), "Capital Account Liberalization and Economic Performance: Survey and Synthesis," IMF Working Paper (May).

Edison, Hali, Ross Levine, Luca Ricci and Torsten Slok (2002), "International Financial Integration and Economic Growth," unpublished manuscript, IMF.

Edwards, Sebastian (2001), "Capital Flows and Economic Performance: Are Emerging Economies Different?” NBER Working Paper no. 8076 (January).

Eichengreen, Barry (1986), "Understanding 1921-1927: Inflation and Economic Recovery in the 1920s," Risita di Storia Economica new ser. 5, pp.34-66.

Eichengreen, Barry (2002a), "Capital Account Liberalization: What Do the Cross Country Studies Show Us?" World Bank Economic Review 15, pp.341-366.

Eichengreen, Barry (2002b), "International Financial Crises: Is the Problem Growing," Jahrbuch fur Wirtschaftsgeschichte 2002/1, pp.89-104.

Eichengreen, Barry and Michael Mussa, with Giovanni Dell-Ariccia, Enrica Detragiache, Gian maria Milesi-Feretti and Andrew Tweedie (1998), "Capital Account liberalization: Theoretical and Practical Aspects,” Occasional Paper no. 1972, Washington, D.C.: IMF (August). 
Eichengreen, Barry and Andrew Rose (1999), "Contagious Currency Crises: Channels of Conveyance," in Takatoshi Ito and Anne Krueger (eds.), Changes in Exchange Rates in Rapidly Growing Economies, Chicago: University of Chicago Press, pp.29-56.

Ellis, Harold (1941), Exchange Control in Central Europe, Cambridge, Mass.: Harvard University Press.

Furman, Jason and Joseph Stiglitz (1998), "Economic Crises: Evidence and Insights from East Asia," Brookings Papers on Economic Activity 2, pp.1-136.

Glick, Reuven and Michael Hutchison (2000), "Stopping 'Hot Money' or Signaling Bad Policy? Capital Controls and the Onset of Currency Crises," unpublished manuscript, Federal Reserve Bank of San Francisco and University of California, Santa Cruz.

Glick, Reuven and Andrew Rose (1999), "Contagion and Trade: Why Are Currency Crises Regional?” Journal of International Money and Finance 18, pp.603-617.

Goldstein, Morris (1998), The Asian Financial Crisis, Washington, D.C.: Institute for International Economics.

Gorinchas, Pierre-Olivier and Olivier Jeanne (2002), "On the Benefits of Capital Account Liberalization for Emerging Economies," unpublished manuscript, Princeton University and IMF (June).

Grilli, Vittorio and Gian Maria Milesi-Ferretti (1995), "Economic Effects and Structural Determinants of Capital Controls," Staff Papers 42, pp.517-551.

International Monetary Fund (various years), Annual Report on Exchange Arrangements and Exchange Restrictions, Washington, D.C.: IMF.

Kaplan, Ethan and Dani Rodrik (2001), "Did the Malaysian Capital Controls Work?" NBER Working Paper no. 8142 (March).

Klein, Michael and Giovanni Olivei (1999), "Capital Account Liberalization, Financial Depth, and Economic Growth," NBER Working Paper no. 7384 (October).

Kraay, Aart (1998), "In Search of the Macroeconomic Effects of Capital Account Liberalization," unpublished manuscript, The World Bank (October).

Krueger, Alan and Mikael Lindahl (2000) "Education for Growth: Why and for Whom?" NBER Working Paper no. 7592 (March).

Krugman, Paul (1998), "Heresy Time," unpublished manuscript, MIT.

Leblang, David A. (2001), "To Devalue or To Defend: The Political Economy of Exchange Rate Policy in the Developing World," unpublished manuscript, University of Colorado, Boulder. 
Levine, Ross and David Renelt (1992), "A Sensitivity Analysis of Cross-Country Growth Regressions," Journal of Monetary Economics 82, pp.942-63

Lindert, Peter L. (2001), "Democracy, Decentralization and Mass Schooling Before 1914." University of California, Davis Agricultural History Research Center Working Paper no. 104.

Maddison, Angus (1995), Monitoring the World Economy 1820-1992, Paris: OECD.

Mitchell, Brian R. (1975), European Historical Statistics, London: Macmillan.

Mitchell, Brian R. (1983), International Historical Statistics: The Americas and Australasia, London: Macmillan.

Nurkse, Ragnar (1944), International Currency Experience, Geneva: League of Nations.

Obstfeld, Maurice and Alan Taylor (2002), "Globalization and Capital Markets," NBER Working Paper no. 8846 (March).

Quinn, Dennis P. (1997), "The Correlates of Changes in International Financial Regulation," American Political Science Review 91, pp. 531-551.

Radelet, Steven and Jeffrey Sachs (2000), "The Onset of the East Asian Financial Crisis," in Paul Krugman (ed.), Currency Crises, Chicago: University of Chicago Press, pp.105-162.

Rodrik, Dani (1998), "Who Needs Capital-Account Convertibility?" in Peter Kenen (ed), Should the IMF Pursue Capital Account Convertibility? Essays in International Finance no. 207, Princeton: Princeton University Press (May).

Salera, Virgil (1941), Exchange Control and the Argentine Market, New York: Columbia University Press.

Stiglitz, Joseph (2002), Globalization and its Discontents, New York: W.W. Norton.

World Bank (2000a), World Development Report, Washington, D.C.: The World Bank.

World Bank (2000b), "Private Capital Flows in Historical Perspective," Chapter 5 of Global Development Finance 2000, Washington, D.C.: World Bank, pp.129-140.

Wyplosz, Charles (1999), "Financial Restraints and Liberalization in Postwar Europe," unpublished manuscript, Graduate Institute of International Studies, Geneva (January). 
Appendix: Descriptive Statistics

\begin{tabular}{|l|l|l|l|l|l|l|l|l|}
\hline & & 1 & 2 & 3 & 4 & 5 & 6 & 7 \\
\hline Growth & & 1.000 & & & & & & \\
\hline Log (gdp per capita) & 1 & -0.009 & 1.000 & & & & & \\
\hline Log (primary enrollment) & 2 & -0.053 & $0.268^{*}$ & 1.000 & & & & \\
\hline Log (secondary Enrollment & 3 & $0.146^{*}$ & $0.733^{*}$ & $0.464^{*}$ & 1.000 & & & \\
\hline Capital Controls-Interwar & 4 & 0.058 & $-0.149^{*}$ & -0.025 & $-0.126^{*}$ & 1.000 & & \\
\hline Capital Controls-BW & 5 & $0.325^{*}$ & -0.018 & 0.039 & $0.150^{*}$ & $-0.123^{*}$ & 1.000 & \\
\hline Capital Controls-Post BW & 6 & 0.022 & $0.289^{*}$ & 0.016 & $0.421^{*}$ & $-0.099^{*}$ & $-0.217^{*}$ & 1.000 \\
\hline Domestic Crises - Pre-1913 & 7 & $-0.119^{*}$ & $-0.223^{*}$ & -0.092 & $-0.259^{*}$ & -0.058 & $-0.127^{*}$ & $-0.102^{*}$ \\
\hline Domestic Crises -- Interwar & 8 & $-0.156^{*}$ & $-0.136^{*}$ & -0.020 & $-0.159^{*}$ & $0.288^{*}$ & $-0.168^{*}$ & $-0.134^{*}$ \\
\hline Domestic Crises - BW & 9 & $0.169^{*}$ & -0.072 & 0.005 & 0.008 & -0.061 & $0.416^{*}$ & $-0.108^{*}$ \\
\hline Domestic Crises -- Post-BW & 10 & -0.037 & $0.173^{*}$ & 0.014 & $0.276^{*}$ & -0.069 & $-0.151^{*}$ & $0.585^{*}$ \\
\hline International Crises - Pre-1913 & 11 & $-0.166^{*}$ & $-0.317^{*}$ & $-0.143^{*}$ & $-0.455^{*}$ & $-0.118^{*}$ & $-0.259^{*}$ & $-0.207^{*}$ \\
\hline International Crises -- Interwar & 12 & $-0.266^{*}$ & $-0.157^{*}$ & 0.034 & $-0.186^{*}$ & $0.296^{*}$ & $-0.216^{*}$ & $-0.173^{*}$ \\
\hline International Crises - BW & 13 & $0.316^{*}$ & 0.051 & $0.121^{*}$ & $0.184^{*}$ & $-0.124^{*}$ & $0.813^{*}$ & $-0.217^{*}$ \\
\hline $\begin{array}{l}\text { International Crises -- Post- } \\
\text { BW }\end{array}$ & 14 & -0.005 & $0.539^{*}$ & 0.037 & $0.577^{*}$ & $-0.124^{*}$ & $-0.272^{*}$ & $0.669^{*}$ \\
\hline
\end{tabular}

\begin{tabular}{|l|l|l|l|l|l|l|l|l|}
\hline & & 8 & 9 & 10 & 11 & 12 & 13 & 14 \\
\hline Domestic Crises - Pre-1913 & 7 & 1.000 & & & & & & \\
\hline Domestic Crises -- Interwar & 8 & -0.079 & 1.000 & & & & & \\
\hline Domestic Crises - BW & 9 & -0.063 & -0.083 & 1.000 & & & & \\
\hline Domestic Crises -- Post-BW & 10 & -0.071 & -0.094 & -0.075 & 1.000 & & & \\
\hline International Crises - Pre-1913 & 11 & $0.289^{*}$ & $-0.160^{*}$ & $-0.129^{*}$ & $-0.144^{*}$ & 1.000 & & \\
\hline International Crises -- Interwar & 12 & $-0.102^{*}$ & $0.709^{*}$ & $-0.107^{*}$ & $-0.120^{*}$ & $-0.206^{*}$ & 1.000 & \\
\hline International Crises - BW & 13 & $-0.128^{*}$ & $-0.168^{*}$ & $0.316^{*}$ & $-0.151^{*}$ & $-0.259^{*}$ & $-0.217^{*}$ & 1.000 \\
\hline $\begin{array}{l}\text { International Crises -- Post- } \\
\text { BW }\end{array}$ & 14 & $-0.128^{*}$ & $-0.169^{*}$ & $-0.135^{*}$ & $0.401^{*}$ & $-0.260^{*}$ & $-0.217^{*}$ & $-0.217^{*}$ \\
\hline
\end{tabular}




\begin{tabular}{|l|l|l|l|l|}
\hline Variable & Mean & StdDev. & Min & Max \\
\hline Growth & 8.582472 & 14.49569 & -43.1428 & 107.2641 \\
\hline Log (gdp per capita) & 8.168666 & 1.047781 & 5.051993 & 10.30307 \\
\hline Log (primary enrollment) & -.5252633 & .6645924 & -2.962856 & 1.625435 \\
\hline Log (secondary Enrollment & -1.760736 & 1.471868 & -6.05424 & 1.917063 \\
\hline Capital Controls-Interwar & .0533981 & .2250993 & 0 & 1 \\
\hline Capital Controls-BW & .2135922 & .4103404 & 0 & 1 \\
\hline Capital Controls-Post BW & .1480583 & .3555895 & 0 & 1 \\
\hline Domestic Crises - Pre-1913 & .0946602 & .3862234 & 0 & 3 \\
\hline Domestic Crises -- Interwar & .1626214 & .5032845 & 0 & 3 \\
\hline Domestic Crises - BW & .0752427 & .2904291 & 0 & 2 \\
\hline Domestic Crises -- Post-BW & .1237864 & .4262862 & 0 & 2 \\
\hline International Crises - Pre-1913 & 1.762136 & 3.547622 & 0 & 14 \\
\hline International Crises -- Interwar & 3.036408 & 7.310702 & 0 & 32 \\
\hline International Crises - BW & 1.458738 & 2.797417 & 0 & 10 \\
\hline $\begin{array}{l}\text { International Crises -- Post- } \\
\text { BW }\end{array}$ & 2.322816 & 4.448698 & 0 & 15 \\
\hline
\end{tabular}


TABLE 1-CAPITAL CONTROLS AND ECONOMIC GROWTH

\begin{tabular}{lllll}
\hline & {$[1]$} & {$[2]$} & {$[3]$} & {$[4]$} \\
& Baseline & $\begin{array}{l}\text { With fixed } \\
\text { effects }\end{array}$ & $\begin{array}{l}\text { Instrumental } \\
\text { variables }\end{array}$ & $\begin{array}{l}\text { Instrumental variable } \\
\text { w/fe }\end{array}$ \\
\hline Constant & $30.71^{*}$ & $79.05^{*}$ & $32.09^{*}$ & $78.85^{*}$ \\
& 11.14 & 22.09 & 16.83 & 34.77 \\
Log (GDP per capita) & $-2.71^{*}$ & $-9.27^{*}$ & -2.85 & $-9.19^{*}$ \\
& 1.20 & 2.60 & 1.79 & 4.04 \\
& & & & \\
Log (primary enroll) & $-2.83^{*}$ & $-4.31^{*}$ & $-2.86^{*}$ & $-4.99^{*}$ \\
& 1.19 & 1.77 & 1.16 & 1.61 \\
Log (secondary enroll) & $2.55^{*}$ & $5.12^{*}$ & & \\
& 0.83 & 1.37 & $1.65^{*}$ & $5.20^{*}$ \\
Capital Controls & & & & 1.97 \\
& $7.22^{*}$ & $9.67^{*}$ & $7.13^{*}$ & $9.80^{*}$ \\
F-test & 1.34 & 1.66 & 1.52 & 1.71 \\
Sargan Test & & & & \\
& $45.10^{*}$ & $58.68^{*}$ & $45.18^{*}$ & $50.92^{*}$ \\
AR(1) Test & 0.0000 & 0.0000 & 0.0000 & 0.0000 \\
& 0.000 & 0.000 & 0.000 & 0.000 \\
N & 1.000 & 1.000 & 1.000 & 1.000 \\
& 1.726 & 1.078 & 1.705 & 1.192 \\
& 0.084 & 0.281 & 0.088 & 0.233 \\
& & & & 412 \\
\hline
\end{tabular}

Dependent Variable: $100 *$ (change in $\log ($ GDP Per Capita) over 5-year period)

Cell entries are parameter estimates obtained using the one-step dynamic panel estimator as described in the text; robust standard errors are in parenthesis; Sargan test is based on the two-step estimator.

F-test is for the variables of interest excluding the fixed effects.

Fixed effects not reported 


\section{TABLE 2-CAPITAL CONTROLS AND ECONOMIC GROWTH-REGIME SPECIFIC RESULTS}

\begin{tabular}{|c|c|c|}
\hline & {$[1]$} & {$[2]$} \\
\hline Constant & $\begin{array}{l}110.77^{*} \\
45.30\end{array}$ & $\begin{array}{l}-96.37^{*} \\
41.38\end{array}$ \\
\hline Log (GDP per capita) & $\begin{array}{l}-14.98 * \\
6.26\end{array}$ & $\begin{array}{l}-13.08^{*} \\
5.89\end{array}$ \\
\hline Log (primary enroll) & $\begin{array}{l}-2.67 \\
1.84\end{array}$ & $\begin{array}{l}-2.89 \\
1.88\end{array}$ \\
\hline Log (secondary enroll) & $\begin{array}{l}3.39 * \\
1.44\end{array}$ & $\begin{array}{l}2.76^{*} \\
1.17\end{array}$ \\
\hline Interwar Period & $\begin{array}{l}2.36 \\
2.14 \\
\end{array}$ & $\begin{array}{l}-0.59 \\
2.25 \\
\end{array}$ \\
\hline Bretton Woods & $\begin{array}{l}18.26^{*} \\
4.79\end{array}$ & $\begin{array}{l}12.72 * \\
6.43\end{array}$ \\
\hline Post Bretton Woods & $\begin{array}{l}21.29^{*} \\
9.02\end{array}$ & $\begin{array}{l}20.27 * \\
9.93\end{array}$ \\
\hline Capital Controls--Interwar & & $\begin{array}{l}10.37^{*} \\
3.59 \\
\end{array}$ \\
\hline Capital Controls --Bretton Woods & & $\begin{array}{l}6.23 \\
3.69 \\
\end{array}$ \\
\hline Capital Controls--Post Bretton Woods & & $\begin{array}{l}-0.52 \\
2.78\end{array}$ \\
\hline F-test & $\begin{array}{l}73.23 * \\
{[0.000]}\end{array}$ & $\begin{array}{l}100.80^{*} \\
0.000\end{array}$ \\
\hline Sargan Test & $\begin{array}{l}0.000 \\
1.000\end{array}$ & $\begin{array}{l}0.000 \\
1.000\end{array}$ \\
\hline AR(1) Test & $\begin{array}{l}0.7171 \\
0.473\end{array}$ & $\begin{array}{l}1.05 \\
0.294\end{array}$ \\
\hline $\mathrm{N}$ & 412 & 412 \\
\hline
\end{tabular}

Dependent Variable: $100 *$ (change in $\log ($ GDP Per Capita) over 5-year period)

Cell entries are parameter estimates obtained using the one-step dynamic panel estimator as described in the text; robust standard errors are in parenthesis; Sargan test is based on the two-step estimator.

F-test is for the variables of interest excluding the fixed effects.

Fixed effects not reported

All models estimated with instrumental variables and country-specific fixed-effects. 
TABLE 3-CAPITAL CONTROLS AND ECONOMIC GROWTH: PERIOD EFFECTS

\begin{tabular}{|c|c|c|}
\hline & $\begin{array}{l}\text { Parameter } \\
\text { Estimate }\end{array}$ & $\begin{array}{l}\text { Robust } \\
\text { Standard Error }\end{array}$ \\
\hline Constant & $156.03^{*}$ & 54.65 \\
\hline Log (GDP per capita) & $-18.29 *$ & 6.56 \\
\hline Log (primary enroll) & -1.04 & 2.31 \\
\hline Log (secondary enroll) & -0.78 & 1.90 \\
\hline Capital Controls*(1919-1923) & $-12.55^{*}$ & 4.82 \\
\hline Capital Controls *(1924-1928) & $17.12 *$ & 3.98 \\
\hline Capital Controls *(1929-1933) & $21.98 *$ & 3.29 \\
\hline Capital Controls *(1934-1939) & -1.13 & 14.01 \\
\hline Capital Controls *(1940-1944) & 19.86 & 15.02 \\
\hline Capital Controls *(1950-1954) & -2.65 & 6.09 \\
\hline Capital Controls *(1955-1959) & -2.02 & 3.25 \\
\hline Capital Controls *(1960-1964) & 6.21 & 6.54 \\
\hline Capital Controls *(1965-1970) & 3.85 & 4.04 \\
\hline Capital Controls *(1973-1977) & 3.61 & 4.83 \\
\hline Capital Controls *(1978-1982) & 1.51 & 5.73 \\
\hline Capital Controls *(1983-1987) & -3.51 & 3.44 \\
\hline Capital Controls *(1988-1992) & -3.37 & 4.09 \\
\hline \multirow[t]{2}{*}{ Capital Controls *(1993-1997) } & $10.17 *$ & 3.95 \\
\hline & $\underline{\text { Test Statistic }}$ & $\underline{\text { Prob }}$ \\
\hline F-test & $153.4^{*}$ & 0.000 \\
\hline Sargan Test & 0.000 & 1.000 \\
\hline AR(1) Test & $2.32 *$ & 0.200 \\
\hline $\mathrm{N}$ & 412 & 412 \\
\hline
\end{tabular}

Dependent Variable: $100 *$ (change in $\log$ (GDP Per Capita) over 5-year period)

Cell entries are parameter estimates obtained using the one-step dynamic panel estimator as described in the text; robust standard errors are in parenthesis; Sargan test is

based on the two-step estimator.

F-test is for the variables of interest excluding the fixed effects.

Fixed effects not reported

Model estimated with a set of $\mathrm{t}-1$ period dummies, not reported. 
TABLE 4-DOMESTIC FINANCIAL CRISES

\begin{tabular}{|c|c|c|c|}
\hline & {$[1]$} & {$[2]$} & {$[3]$} \\
\hline Constant & $\begin{array}{l}108.28 * \\
(41.56)\end{array}$ & $\begin{array}{l}106.36^{*} \\
(40.31)\end{array}$ & $\begin{array}{l}108.61 * \\
(46.22)\end{array}$ \\
\hline Log (GDP per capita) & $\begin{array}{c}-14.24^{*} \\
(5.89) \\
\end{array}$ & $\begin{array}{l}-14.26^{*} \\
(5.76)\end{array}$ & $\begin{array}{l}-14.63^{*} \\
(6.45)\end{array}$ \\
\hline Log (primary enroll) & $\begin{array}{l}-3.57^{*} \\
(1.81) \\
\end{array}$ & $\begin{array}{l}-3.65^{*} \\
(1.82) \\
\end{array}$ & $\begin{array}{l}-3.77^{*} \\
(1.81) \\
\end{array}$ \\
\hline Log (secondary enroll) & $\begin{array}{l}3.42 * \\
(1.29)\end{array}$ & $\begin{array}{l}3.03^{*} \\
(1.24)\end{array}$ & $\begin{array}{l}3.23 * \\
(1.34)\end{array}$ \\
\hline Interwar Period & $\begin{array}{c}3.50 \\
(2.06)\end{array}$ & $\begin{array}{l}4.16^{*} \\
(2.07)\end{array}$ & $\begin{array}{l}4.24 * \\
(2.12)\end{array}$ \\
\hline Bretton Woods & $\begin{array}{l}12.43^{*} \\
(5.55)\end{array}$ & $\begin{array}{l}14.23^{*} \\
(5.72)\end{array}$ & $\begin{array}{l}14.64^{*} \\
(5.42)\end{array}$ \\
\hline Post Bretton Woods & $\begin{array}{l}17.22 \\
(9.33) \\
\end{array}$ & $\begin{array}{l}18.56^{*} \\
(9.37) \\
\end{array}$ & $\begin{array}{l}18.59^{*} \\
(9.57)\end{array}$ \\
\hline Capital Controls & $\begin{array}{l}6.23^{*} \\
(2.51)\end{array}$ & $\begin{array}{l}4.16 \\
(2.78)\end{array}$ & $\begin{array}{l}3.27 \\
(2.20)\end{array}$ \\
\hline Domestic Crises & $\begin{array}{l}-3.26^{*} \\
(1.00)\end{array}$ & $\begin{array}{l}-4.52^{*} \\
(1.16)\end{array}$ & \\
\hline Controls * Crises & & $\begin{array}{l}3.18 \\
(1.68)\end{array}$ & \\
\hline Crises- (Controls*Crises) & & & $\begin{array}{l}-4.53^{*} \\
(1.16)\end{array}$ \\
\hline F-test & $\begin{array}{l}103.00^{*} \\
{[0.000]}\end{array}$ & $\begin{array}{l}110.10^{*} \\
{[0.000]}\end{array}$ & $\begin{array}{l}110.60 * \\
{[0.000]}\end{array}$ \\
\hline Sargan Test & $\begin{array}{c}0.000 \\
{[1.000]}\end{array}$ & $\begin{array}{l}0.000 \\
{[1.000]}\end{array}$ & $\begin{array}{l}0.000 \\
{[1.000]}\end{array}$ \\
\hline AR(1) Test & $\begin{array}{c}1.30 \\
{[0.194]}\end{array}$ & $\begin{array}{l}1.32 \\
{[0.188]}\end{array}$ & $\begin{array}{l}1.302 \\
{[0.193]}\end{array}$ \\
\hline
\end{tabular}

F-test for unrestricted (model 2) v restricted (model 3): $\mathrm{F}=0.41(\mathrm{p}=0.5176)$

Dependent Variable: $100 *$ (change in log(GDP Per Capita) over 5-year period)

Cell entries are parameter estimates obtained using the one-step dynamic panel estimator as described in the text; robust standard errors are in parenthesis; Sargan test is based on the two-step estimator.

F-test is for the variables of interest excluding the fixed effects. Fixed effects not reported. 
TABLE 5-DOMESTIC FINANCIAL CRISES-REGIME SPECIFIC RESULTS

\begin{tabular}{lll}
\hline & {$[1]$} & {$[2]$} \\
\hline Constant & $95.38^{*}$ & $94.88^{*}$ \\
& 31.32 & 37.51 \\
\hline Log (GDP per capita) & $-12.94^{*}$ & $-12.85^{*}$ \\
& 4.56 & 5.38 \\
\hline Log (primary enroll) & -3.21 & -3.41 \\
& 2.08 & 1.90 \\
\hline Log (secondary enroll) & $2.53^{*}$ & $2.71^{*}$ \\
& 1.08 & 1.11 \\
\hline InterWar Period & 4.54 & 4.37 \\
& 2.58 & 2.61 \\
\hline Bretton Woods & $10.93^{*}$ & 10.62 \\
& 5.23 & 6.17 \\
\hline Post Bretton Woods & $19.92^{*}$ & $19.41^{*}$ \\
& 8.45 & 9.23 \\
\hline Controls-Interwar Period & 7.23 & 4.84 \\
& 5.35 & 3.54 \\
\hline Controls-Bretton Woods & $6.84^{*}$ & $7.73^{*}$ \\
& 2.99 & 3.31 \\
\hline Controls-Post Bretton Woods & 1.41 & -0.42 \\
& 3.15 & 3.11 \\
\hline Crisis-Pre-1913 & $-3.94^{*}$ & $-3.99^{*}$ \\
& 1.17 & 1.20 \\
\hline Crisis-Interwar & $-5.11^{*}$ & \\
\hline Crisis-Bretton Woods & 2.57 & \\
\hline Crisis-Post BW & 1.08 & \\
\hline
\end{tabular}




\begin{tabular}{lll}
\hline Controls* Crisis-Interwar & 1.76 & \\
& 3.84 & \\
\hline Controls* Crisis: Bretton Woods & 1.90 & \\
& 4.51 & \\
\hline Controls* Crisis: Post-Bretton & 1.39 & \\
Woods & 3.42 & \\
\hline Crisis - & & $-5.054^{*}$ \\
(Controls*Crisis)-Interwar & 2.51 \\
\hline Crisis - (Controls*Crisis)-Bretton & & 1.244 \\
Wood & & 4.27 \\
\hline Crisis - (Controls*Crisis)-Post & & -3.89 \\
BW & $268.00^{*}$ & $246.20^{*}$ \\
\hline F-test & 0.000 & 0.000 \\
& 0.000 & 0.000 \\
Sargan Test & 1.000 & 1.000 \\
& 1.522 & 1.385 \\
AR(1) Test & 0.128 & 0.166 \\
& 412 & 412 \\
\hline
\end{tabular}

F-test for unrestricted (model 1) v restricted (model 2): $\mathrm{F}=0.99(\mathrm{p}=0.3965)$

Dependent Variable: $100 *$ (change in $\log$ (GDP Per Capita) over 5-year period)

Cell entries are parameter estimates obtained using the one-step

dynamic panel estimator as described in the text; robust standard errors are

reported below the coefficients; Sargan test is based on the two-step estimator.

F-test is for the variables of interest excluding the fixed effects.

Fixed effects not reported 
TABLE 6-INTERNATIONAL FINANCIAL CRISES

\begin{tabular}{|c|c|c|c|}
\hline & {$[1]$} & {$[2]$} & {$[3]$} \\
\hline Constant & $\begin{array}{c}103.72 * \\
43.12\end{array}$ & $\begin{array}{l}\text { 113.54* } \\
42.88\end{array}$ & $\begin{array}{l}106.84 * \\
41.72\end{array}$ \\
\hline Log (GDP per capita) & $\begin{array}{c}-13.97^{*} \\
6.05\end{array}$ & $\begin{array}{l}-15.00 * \\
5.91\end{array}$ & $\begin{array}{l}-14.28^{*} \\
5.80\end{array}$ \\
\hline Log (primary enroll) & $\begin{array}{c}-3.16 \\
1.84\end{array}$ & $\begin{array}{l}-3.28 \\
2.07\end{array}$ & $\begin{array}{l}-2.91 \\
1.85\end{array}$ \\
\hline Log (secondary enroll) & $\begin{array}{c}2.79^{*} \\
1.41\end{array}$ & $\begin{array}{l}3.13^{*} \\
1.41\end{array}$ & $\begin{array}{l}2.62^{*} \\
1.37\end{array}$ \\
\hline Interwar Period & $\begin{array}{l}8.16^{*} \\
2.99\end{array}$ & $\begin{array}{l}8.59 * \\
3.04\end{array}$ & $\begin{array}{l}9.00^{*} \\
2.67\end{array}$ \\
\hline Bretton Woods & $\begin{array}{c}15.31^{*} \\
5.76\end{array}$ & $\begin{array}{l}18.53^{*} \\
6.33\end{array}$ & $\begin{array}{l}19.15^{*} \\
5.57\end{array}$ \\
\hline Post Bretton Woods & $\begin{array}{c}21.42 * \\
9.36\end{array}$ & $\begin{array}{l}22.73 * \\
9.10\end{array}$ & $\begin{array}{l}23.28 * \\
9.15\end{array}$ \\
\hline Capital Controls & $\begin{array}{l}4.11 \\
2.28\end{array}$ & $\begin{array}{l}-3.46 \\
1.15\end{array}$ & $\begin{array}{l}-3.43 \\
2.22\end{array}$ \\
\hline International Crises & $\begin{array}{c}-0.61 * \\
0.11\end{array}$ & $\begin{array}{l}-0.69 * \\
0.11\end{array}$ & \\
\hline Controls * Crises & & $\begin{array}{l}0.74 * \\
0.33\end{array}$ & \\
\hline Crises- (Controls*Crises) & & & $\begin{array}{l}-0.700 * \\
0.11\end{array}$ \\
\hline F-test & $\begin{array}{l}184.80^{*} \\
{[0.000]}\end{array}$ & $\begin{array}{l}222.20^{*} \\
{[0.000]}\end{array}$ & $\begin{array}{l}235.90 * \\
{[0.000]}\end{array}$ \\
\hline Sargan Test & $\begin{array}{c}0.000 \\
{[1.000]}\end{array}$ & $\begin{array}{l}0.000 \\
{[1.000]}\end{array}$ & $\begin{array}{l}0.000 \\
{[1.000]}\end{array}$ \\
\hline AR(1) Test & $\begin{array}{c}1.498 \\
{[0.134]}\end{array}$ & $\begin{array}{l}1.443 \\
{[0.149]}\end{array}$ & $\begin{array}{l}1.364 \\
{[0.225]}\end{array}$ \\
\hline
\end{tabular}

F-test for unrestricted (model 2) v restricted (model 3): $\mathrm{F}=0.00(\mathrm{p}=1.00)$

Dependent Variable: $100 *$ (change in $\log$ (GDP Per Capita) over 5-year period)

Cell entries are parameter estimates obtained using the one-step dynamic panel estimator as described in the text; robust standard errors are in parenthesis; Sargan test is based on the two-step estimator.

F-test is for the variables of interest excluding the fixed effects. Fixed effects not reported. 
TABLE 7-INTERNATIONAL FINANCIAL CRISES-REGIME SPECIFIC RESULTS

\begin{tabular}{|c|c|c|}
\hline & [1] & [2] \\
\hline \multirow[t]{2}{*}{ Constant } & $82.97 *$ & $89.59 *$ \\
\hline & 31.66 & 38.87 \\
\hline \multirow[t]{2}{*}{ Log (GDP per capita) } & $-10.58^{*}$ & $-11.60 *$ \\
\hline & 4.37 & 5.49 \\
\hline \multirow[t]{2}{*}{ Log (primary enroll) } & -3.30 & -3.12 \\
\hline & 1.78 & 1.83 \\
\hline \multirow[t]{2}{*}{ Log (secondary enroll) } & $3.01 *$ & $3.02 *$ \\
\hline & 1.21 & 1.20 \\
\hline \multirow[t]{2}{*}{ InterWar Period } & $12.96^{*}$ & $12.91 *$ \\
\hline & 3.61 & 3.69 \\
\hline \multirow[t]{2}{*}{ Bretton Woods } & $13.13^{*}$ & $14.05^{*}$ \\
\hline & 5.38 & 5.80 \\
\hline \multirow[t]{2}{*}{ Post Bretton Woods } & 11.03 & 12.87 \\
\hline & 8.42 & 10.10 \\
\hline \multirow[t]{2}{*}{ Controls-Interwar Period } & 0.03 & -5.42 \\
\hline & 4.75 & 4.36 \\
\hline \multirow[t]{2}{*}{ Controls-Bretton Woods } & -6.10 & 1.56 \\
\hline & 5.03 & 4.12 \\
\hline \multirow[t]{2}{*}{ Controls-Post Bretton Woods } & 5.37 & 1.74 \\
\hline & 6.89 & 4.23 \\
\hline \multirow[t]{2}{*}{ Crisis-Pre-1913 } & -0.32 & -0.34 \\
\hline & 0.22 & 0.22 \\
\hline \multirow[t]{2}{*}{ Crisis-Interwar } & $-0.92 *$ & \\
\hline & 0.17 & \\
\hline \multirow[t]{2}{*}{ Crisis-Bretton Woods } & -0.61 & \\
\hline & 0.90 & \\
\hline Crisis-Post BW & 0.16 & \\
\hline
\end{tabular}




\begin{tabular}{lll}
\hline & 0.30 & \\
\hline Controls* Crisis-Interwar Period & 0.45 & \\
& 0.31 & \\
\hline Controls* Crisis-Bretton Woods & $1.97^{*}$ & \\
& 1.00 & \\
\hline Controls*Crisis-Post-Bretton Woods & -0.52 & \\
& 0.62 & \\
\hline Crisis - (Controls*Crisis)--Interwar & & $-0.32^{*}$ \\
& & 0.17 \\
\hline Crisis - (Controls*Crisis)-Bretton Woods & & -0.59 \\
& & 0.89 \\
\hline Crisis - (Controls*Crisis)-Post Bretton & & 0.16 \\
Woods & 0.31 \\
\hline F-test & $321.30^{*}$ & $168.10^{*}$ \\
& 0.000 & 0.000 \\
\hline Sargan Test & 0.000 & 0.000 \\
& 1.000 & 1.000 \\
\hline AR(1) Test & 1.105 & 1.210 \\
& 0.269 & 0.226 \\
\hline $\mathrm{N}$ & 412 & \\
\hline
\end{tabular}

$\mathrm{N}$ 412

F-test for unrestricted (model 1) v restricted (model 2): $\mathrm{F}=2.11(\mathrm{p}=0.0987)$

Dependent Variable: $100 *$ (change in $\log$ (GDP Per Capita) over 5-year period)

Cell entries are parameter estimates obtained using the one-step dynamic panel estimator as described in the text; robust standard errors are in parenthesis; Sargan test is based on the two-step estimator.

F-test is for the variables of interest excluding the fixed effects.

Fixed effects not reported 
TABLE 8-Domestic \& International Crises

\begin{tabular}{lcll}
\hline & {$[1]$} & {$[2]$} & {$[3]$} \\
\hline Constant & $102.70^{*}$ & $103.18^{*}$ & $110.61^{*}$ \\
& 37.99 & 37.66 & 41.55 \\
\hline Log (GDP per capita) & $-13.60^{*}$ & $-13.58^{*}$ & $-14.59^{*}$ \\
& 5.51 & 5.43 & 5.98 \\
\hline Log (primary enroll) & -2.87 & -2.96 & -3.19 \\
& 1.91 & 2.01 & 2.23 \\
\hline Log (secondary enroll) & $2.56^{*}$ & $2.54^{*}$ & $2.93^{*}$ \\
& 1.17 & 1.15 & 1.13 \\
\hline Interwar Period & $8.68^{*}$ & $9.00^{*}$ & $8.82^{*}$ \\
& 3.00 & 3.06 & 3.06 \\
\hline Bretton Woods & $14.61^{*}$ & $17.67^{*}$ & $17.76^{*}$ \\
& 5.79 & 6.55 & 5.98 \\
\hline Post Bretton Woods & $21.33^{*}$ & $21.78^{*}$ & $22.07^{*}$ \\
& 9.38 & 9.43 & 10.00 \\
\hline Capital Controls & $4.85^{*}$ & -2.25 & -2.86 \\
& 2.28 & 4.09 & 2.38 \\
\hline Domestic Crises & $-2.47^{*}$ & $-2.72^{*}$ & \\
& 1.04 & 1.25 & \\
\hline International Crises & $-0.55^{*}$ & $-0.61^{*}$ & \\
& 0.11 & 0.11 & \\
\hline Controls * Domestic Crises & & 1.34 & \\
& & 1.97 & \\
\hline Controls * International Crises & & 0.61 & \\
\hline Domestic Crises-(Controls * & 0.31 & \\
\hline \hline
\end{tabular}




\begin{tabular}{lcll}
\hline $\begin{array}{l}\text { International Crises- } \\
\text { (Controls*IC) }\end{array}$ & & & $-0.60^{*}$ \\
& & & 0.11 \\
\hline F-test & $191.30^{*}$ & $289.600^{*}$ & $250.30^{*}$ \\
& {$[0.000]$} & {$[0.000]$} & {$[0.000]$} \\
Sargan Test & 0.000 & 0.000 & 0.000 \\
& {$[1.000]$} & {$[1.000]$} & {$[1.000]$} \\
AR(1) Test & $1.549[0.1$ & $1.377[0.1$ & $1.463[0.144]$ \\
& $34]$ & $49]$ & \\
\hline
\end{tabular}

F-test for unrestricted (model 2) v restricted (model 3): $F=0.71(p=0.492)$

Dependent Variable: $100 *$ (change in $\log$ (GDP Per Capita) over 5-year period)

Cell entries are parameter estimates obtained using the one-step dynamic panel estimator as described in the text; robust standard errors are in parenthesis; Sargan test is based on the twostep estimator.

F-test is for the variables of interest excluding the fixed effects.

Fixed effects not reported 
Table 9-ADDITIONAL EVIDENCE FOR THE RECENT ERA

\begin{tabular}{|c|c|c|c|c|c|c|c|c|c|}
\hline & {$[1]$} & {$[2]$} & {$[3]$} & {$[4]$} & {$[5]$} & {$[6]$} & {$[7]$} & {$[8]$} & [9] \\
\hline Constant & \begin{tabular}{|l}
$34.25 *$ \\
13.68 \\
\end{tabular} & $\begin{array}{l}40.82^{*} \\
12.32 \\
\end{array}$ & $\begin{array}{l}45.51^{*} \\
12.99 \\
\end{array}$ & $\begin{array}{l}55.18^{*} \\
13.70 \\
\end{array}$ & $\begin{array}{l}58.02 * \\
12.47 \\
\end{array}$ & $\begin{array}{l}56.19^{*} \\
13.15 \\
\end{array}$ & $\begin{array}{l}53.74^{*} \\
11.75 \\
\end{array}$ & $\begin{array}{l}55.99^{*} \\
11.55 \\
\end{array}$ & $\begin{array}{l}55.11^{*} \\
10.97 \\
\end{array}$ \\
\hline Log (GDP per capita) & $\begin{array}{l}-3.68^{*} \\
1.85 \\
\end{array}$ & $\begin{array}{l}-4.49^{*} \\
1.56 \\
\end{array}$ & $\begin{array}{l}-4.94^{*} \\
1.75 \\
\end{array}$ & $\begin{array}{l}-4.94^{*} \\
1.79 \\
\end{array}$ & $\begin{array}{l}-5.24^{*} \\
1.58 \\
\end{array}$ & $\begin{array}{l}-5.80^{*} \\
1.68 \\
\end{array}$ & $\begin{array}{l}-4.68^{*} \\
1.52 \\
\end{array}$ & $\begin{array}{l}-5.11^{*} \\
1.42 \\
\end{array}$ & $\begin{array}{l}-5.59^{*} \\
1.58 \\
\end{array}$ \\
\hline School & $\begin{array}{l}-2.58 \\
2.87 \\
\end{array}$ & $\begin{array}{l}-1.78 \\
2.65 \\
\end{array}$ & $\begin{array}{l}-1.43 \\
2.69 \\
\end{array}$ & $\begin{array}{l}3.05 \\
2.15 \\
\end{array}$ & $\begin{array}{l}2.66 \\
2.25 \\
\end{array}$ & $\begin{array}{l}-0.11 \\
2.53 \\
\end{array}$ & $\begin{array}{l}-3.56 \\
2.31 \\
\end{array}$ & $\begin{array}{l}-3.33 \\
2.28 \\
\end{array}$ & $\begin{array}{l}-0.54 \\
2.61 \\
\end{array}$ \\
\hline $\begin{array}{l}\text { Government } \\
\text { Consumption }\end{array}$ & $\begin{array}{l}-2.53 \\
1.93 \\
\end{array}$ & $\begin{array}{l}-2.36 \\
1.87 \\
\end{array}$ & $\begin{array}{l}-2.89 \\
1.82 \\
\end{array}$ & $\begin{array}{l}-3.19 \\
1.82 \\
\end{array}$ & $\begin{array}{l}-3.16 \\
1.87 \\
\end{array}$ & $\begin{array}{l}-2.73 \\
1.93 \\
\end{array}$ & $\begin{array}{l}-4.28^{*} \\
1.55 \\
\end{array}$ & $\begin{array}{l}-4.09^{*} \\
1.52 \\
\end{array}$ & $\begin{array}{l}-4.14^{*} \\
1.67 \\
\end{array}$ \\
\hline Log(inflation) & $\begin{array}{l}-2.17 \\
1.31 \\
\end{array}$ & $\begin{array}{l}-2.13 \\
1.24 \\
\end{array}$ & $\begin{array}{l}-2.60 * \\
1.24 \\
\end{array}$ & $\begin{array}{l}-3.14^{*} \\
1.26 \\
\end{array}$ & $\begin{array}{l}-2.86^{*} \\
1.28 \\
\end{array}$ & $\begin{array}{l}-3.47^{*} \\
1.44 \\
\end{array}$ & $\begin{array}{l}-0.64 \\
1.81 \\
\end{array}$ & $\begin{array}{l}-1.06 \\
1.68 \\
\end{array}$ & $\begin{array}{l}-1.76 \\
1.51 \\
\end{array}$ \\
\hline $\log (\mathrm{BMP})$ & $\begin{array}{l}-1.42 * \\
0.53 \\
\end{array}$ & $\begin{array}{l}-1.53^{*} \\
0.52 \\
\end{array}$ & $\begin{array}{l}-1.68^{*} \\
0.51 \\
\end{array}$ & $\begin{array}{l}-1.46^{*} \\
0.49 \\
\end{array}$ & $\begin{array}{l}-1.50^{*} \\
0.51 \\
\end{array}$ & $\begin{array}{l}-1.45^{*} \\
0.49 \\
\end{array}$ & $\begin{array}{l}-1.85^{*} \\
0.81 \\
\end{array}$ & $\begin{array}{l}-1.85^{*} \\
0.82 \\
\end{array}$ & $\begin{array}{l}-2.03^{*} \\
0.65 \\
\end{array}$ \\
\hline Trade Openness & $\begin{array}{l}3.07^{*} \\
1.39 \\
\end{array}$ & $\begin{array}{l}2.98 * \\
1.26 \\
\end{array}$ & $\begin{array}{l}2.91 * \\
1.19 \\
\end{array}$ & $\begin{array}{l}1.91 \\
1.16 \\
\end{array}$ & $\begin{array}{l}1.91 \\
1.12 \\
\end{array}$ & $\begin{array}{l}2.56^{*} \\
1.17 \\
\end{array}$ & $\begin{array}{l}2.12^{*} \\
1.08 \\
\end{array}$ & $\begin{array}{l}2.24^{*} \\
1.02 \\
\end{array}$ & $\begin{array}{l}2.42^{*} \\
1.08 \\
\end{array}$ \\
\hline Capital Controls & $\begin{array}{l}2.27^{*} \\
1.75\end{array}$ & $\begin{array}{l}0.28 \\
1.01\end{array}$ & $\begin{array}{l}-0.30 \\
0.93\end{array}$ & $\begin{array}{l}1.01 \\
0.98\end{array}$ & $\begin{array}{l}-0.65 \\
2.18\end{array}$ & $\begin{array}{l}-5.00^{*} \\
1.91\end{array}$ & $\begin{array}{l}1.57^{*} \\
0.80\end{array}$ & $\begin{array}{l}3.08 \\
2.06\end{array}$ & $\begin{array}{l}-2.73 \\
1.53\end{array}$ \\
\hline Domestic Crises & $\begin{array}{l}-0.61^{*} \\
0.17 \\
\end{array}$ & $\begin{array}{l}-0.99 * \\
0.46 \\
\end{array}$ & & & & & $\begin{array}{l}-0.58^{*} \\
0.17 \\
\end{array}$ & $\begin{array}{l}-0.70 \\
0.43 \\
\end{array}$ & \\
\hline $\begin{array}{l}\text { Controls * Domestic } \\
\text { Crises }\end{array}$ & & $\begin{array}{l}0.54 \\
0.53 \\
\end{array}$ & & & & & & $\begin{array}{l}0.15 \\
0.48 \\
\end{array}$ & \\
\hline International Crises & & & & $\begin{array}{l}-0.13^{*} \\
0.02 \\
\end{array}$ & $\begin{array}{l}-0.16^{*} \\
0.06\end{array}$ & & $\begin{array}{l}-0.12 * \\
0.02 \\
\end{array}$ & $\begin{array}{l}-0.06 \\
0.04\end{array}$ & \\
\hline $\begin{array}{l}\text { Controls* International } \\
\text { Crisis }\end{array}$ & & & & & $\begin{array}{l}0.03 \\
0.07 \\
\end{array}$ & & & $\begin{array}{l}-0.07 \\
0.06 \\
\end{array}$ & \\
\hline $\begin{array}{l}\text { Domestic Crises - } \\
\text { (Controls* Domestic } \\
\text { Crises) }\end{array}$ & & & $\begin{array}{l}-1.02 * \\
0.45\end{array}$ & & & & & & $\begin{array}{r}-0.71 \\
0.39\end{array}$ \\
\hline
\end{tabular}




\begin{tabular}{|l|l|l|l|l|l|l|l|l|l|}
\hline $\begin{array}{l}\text { International Crisis- } \\
\text { (controls*intl. crisis) }\end{array}$ & & & & & & $\begin{array}{l}-0.16^{*} \\
0.06\end{array}$ & & $\begin{array}{l}-0.09^{*} \\
0.05\end{array}$ \\
\hline F-test & $\begin{array}{l}134.00^{*} \\
0.000\end{array}$ & $\begin{array}{l}110.00^{*} \\
0.000\end{array}$ & $\begin{array}{l}127.2^{*} \\
0.000\end{array}$ & $\begin{array}{l}112.40^{*} \\
0.000\end{array}$ & $\begin{array}{l}93.39^{*} \\
0.000\end{array}$ & $\begin{array}{l}99.91^{*} \\
0.000\end{array}$ & $\begin{array}{l}86.03^{*} \\
0.000\end{array}$ & $\begin{array}{l}88.95^{*} \\
0.000\end{array}$ & $\begin{array}{l}97.03^{*} \\
0.000\end{array}$ \\
\hline Sargan Test & 49.54 & 56.47 & 51.03 & 43.90 & 44.18 & 52.19 & 13.82 & 0.000 & 0.000 \\
& 0.086 & 0.054 & 0.067 & 0.172 & 0.299 & 0.068 & 1.000 & 1.000 & 1.000 \\
\hline AR(1) Test & -1.69 & -1.81 & $-1.91^{*}$ & -1.067 & -1.020 & -1.56 & -1.87 & $-1.95^{*}$ & $-2.04^{*}$ \\
& 0.097 & 0.079 & 0.051 & 0.113 & 0.109 & 0.098 & 0.078 & 0.50 & 0.023 \\
\hline $\mathrm{N}$ & 183 & 183 & 183 & 183 & 183 & 183 & 183 & 183 & 183 \\
\hline
\end{tabular}

Domestic: F-test for unrestricted (model 2) v restricted (model 3): $\mathrm{F}=4.08(\mathrm{p}=0.0455)$

International F-test for unrestricted (model 5) v restricted (model 6): $\mathrm{F}=7.47(\mathrm{p}=0.0071)$

Domestic \& Int. F-test for unrestricted (model 8) v restricted (model 9): $F=7.06(p=0.0012)$

Dependent Variable: $100 *$ (change in $\log$ (GDP Per Capita) over 5-year period)

Cell entries are parameter estimates obtained using the one-step dynamic panel estimator as described in the text; robust standard errors are in parenthesis; Sargan test is based on the two-step estimator.

F-test is for the variables of interest excluding the fixed effects.

Fixed effects not reported 